\title{
Persepsi tekanan akademik dan kesejahteraan diri di dalam kalangan pelajar universiti di Serdang, Selangor
}

\author{
Perception of academic stress, and student's well-being among university students in Serdang, \\ Selangor
}

\author{
Mohammad Arif Bin Johari, Sa'odah Ahmad \\ Jabatan Pembangunan Manusia dan Pengajian Keluarga, Fakulti Ekologi Manusia, \\ Universiti Putra Malaysia, Serdang, Selangor, Malaysia \\ e-mel: m.arifjo@outlook.com, saodahahmad@upm.edu.my
}

DOI: https://doi.org/10.37134/ejoss.vol5.1.4.2019

\begin{abstract}
Abstrak
Kajian ini telah dijalankan untuk menentukan perkaitan antara persepsi tekanan akademik dengan kesejahteraan diri dalam kalangan pelajar universiti di Serdang, Selangor. Seramai 400 orang pelajar telah dipilih sebagai responden kajian dan data dikumpul menggunakan borang soal selidik yang diisi sendiri oleh responden. Skala Personal Wellbeing Index Adult (PWI-A) oleh Cummins (2013) digunakan untuk mengukur tahap kesejahteraan diri pelajar universiti. Pesepsi tekanan akademik pula telah diukur dengan menggunakan Perception of Academic Stress Scale (PAS) oleh Bedewy dan Gabriel (2015) yang mempunyai empat sub-skala iaitu tekanan prestasi, persepsi bebanan kerja, persepsi diri akademik dan kekangan masa. Hasil kajian menunjukkan terdapat perkaitan yang signifikan antara persepsi diri akademik $(\mathrm{r}=$ $\left.0.247^{* *}, \mathrm{p} \leq 0.05\right)$ dan kekangan masa $\left(\mathrm{r}=0.179^{* *}, \mathrm{p} \leq 0.05\right)$ dengan kesejahteraan diri pelajar universiti. Kajian ini membuktikan persepsi diri akademik merupakan faktor peramal yang paling kuat dalam menentukan kesejahteraan diri pelajar universiti $(\beta=0.230)$. Ini bermaksud kesejahteraan diri pelajar universiti amat dipengaruhi oleh faktor bagaimana mereka mempersepsi diri dari aspek akademik. Keyakinan tinggi seseorang pelajar terhadap kemampuan akademiknya boleh menjadi motivasi kepada usaha yang difokuskan untuk mencapai kejayaan. Persepsi diri akademik yang positif memudahkan seseorang pelajar menyesuaikan diri dengan persekitaran dan kaedah pembelajaran di university.
\end{abstract}

Kata Kunci kesejahteraan diri, pelajar universiti, tekanan akademik

\begin{abstract}
This study was conducted to determine the correlation between the perceptions of academic stress with the well-being of university students in Serdang, Selangor. A total of 400 university students were selected as respondents for the study and data was gathered using a self-administered questionnaire. The Personal Wellbeing Index-Adult (PWI-A) by Cummins (2013) was used to measure the university student's level of well-being. Academic stress was measured using the Perception of Academic Stress Scale (PAS) by Bedewy \& Gabriel (2015) which consists of four sub-scales: pressure to perform, work-load perception, academic self-perception, and time restraint. The results showed that there was a significant correlation between the pressure to perform $\left(r=0.247^{* *}, p \leq 0.05\right)$, and time restraint $\left(r=0.179^{* *}, p \leq\right.$ $0.05)$ with the university student's wellbeing. The study proved that academic self-perception $(\beta=0.230)$ was the strongest predictor of the university student's well-being $\left(\beta=0.230, r^{2}=0.120\right)$. This means that university students' well-being was influenced by how they perceived themselves academically. A student's high confidence in his academic ability can be a motivation to focus effort on achieving success. Positive academic self-perception facilitates student's adjustment with the university's environment and learning styles.
\end{abstract}

Keywords student's well-being, academic stress

\section{PENGENALAN}


Kesejahteraan diri merujuk kepada cara hidup yang optimum merangkumi aspek fizikal, mental dan spiritual yang diintegrasikan oleh individu untuk kehidupan yang berkualiti dalam masyarakat (Myers, Sweeney \& Wittmer, 2005). Jarden (2012) pula mendefinisikan kesejahteraan diri/psikologi sebagai kebahagiaan, kepuasan hidup dan pertumbuhan peribadi. Kesejahteraan diri/psikologi adalah aspek penting yang menentukan kebahagiaan dan kesihatan mental individu. Menurut Kajian Kesihatan Morbiditi Kebangsaan di Malaysia (2011), kesihatan mental individu berumur 16 tahun ke atas telah meningkat kepada 29.2\% (dianggarkan sebanyak 4.2 juta orang - kira-kira 1 dalam 3 rakyat Malaysia menghadapi masalah mental). Statistik ini menjelaskan bahawa kesejahteraan diri dalam kalangan golongan muda di Malaysia semakin menurun dan fenomena ini menggambarkan kehidupan mereka kurang berkualiti. Kehidupan yang kurang berkualiti akan menjejaskan perkembangan optimal individu dan kelangsungan generasi masa hadapan negara.

Tidak dinafikan tekanan akademik merupakan salah satu masalah yang sering dihadapi oleh pelajar universiti. Kebanyakan pelajar universiti mengalami kejutan budaya dan pengalaman akademik kerana kehidupan di universiti adalah berbeza dengan kehidupan yang mereka lalui sebelum ini di sekolah. Sebagai pelajar universiti mereka perlu melakukan adaptasi kepada sistem pembelajaran dan pengajaran serta cara hidup dan persekitaran sosial universiti. Selain itu, pelajar universiti secara khususnya perlu mencapai tahap lulus minimum yang ditetapkan untuk membolehkan mereka bergraduat.

Kegagalan pelajar universiti untuk melakukan adaptasi, memenuhi keperluan-keperluan baharu dan seterusnya mengatasi tekanan yang dialami boleh menyebabkan penurunan tahap kesejahteraan diri, kemerosotan prestasi akademik dan peningkatan tekanan psikologi (Dwyer \& Cummings, 2001). Peningkatan tekanan akademik pada tahun pertama akan mempengaruhi pencapaian purata keseluruhan markah gred akademik (GPA) pada tahun-tahun berikutnya (Wintre \& Yaffe, 2000). Tekanan akademik yang semakin meningkat juga menyebabkan pelajar universiti cenderung untuk hilang keyakinan diri (Tao et al., 2000; Dwyer \& Cummings, 2001), mengalami depresi, kemurungan dan terjebak dalam masalah tingkah laku negatif (Deb, Stoudl \& Sun, 2015; King, Vidowel \& Sigh, 2014; Bennett \& Holloway, 2014).

Kesan tekanan akademik berbeza bergantung kepada bagaimana pelajar bertindak terhadap tekanan yang dihadapi. Jika tekanan dilihat sebagai sesuatu yang negatif, maka ia akan memberi kesan buruk kepada kesihatan fizikal, mental, emosi dan prestasi akademik pelajar berkenaan. Sebaliknya, jika tekanan dilihat secara positif, ia akan menjadi sumber dan motivasi kepada pelajar berkenaan untuk mencapai keputusan akademik yang lebih baik dari sebelumnya

Dapat dirumuskan bahawa kehidupan di universiti adalah satu tempoh masa yang sangat penting kerana di sinilah pelajar membentuk nilai-nilai kemanusian, pandangan hidup, sifat resilien dan kemandirian. Universiti bukan sahaja menyediakan ruang dan peluang untuk individu menyambung pengajian tetapi juga merupakan tempat di mana mereka mempelajari dan mengamalkan kemahiran bersosialisasi serta mengalami perkembangan psikologi sebagai individu dewasa. Sebarang bentuk cabaran yang dihadapi di universiti boleh menjadi punca tekanan yang jika gagal ditangani akan memberi kesan kepada kesejahteraan psikologi, fizikal dan prestasi akademik pelajar universiti serta dalam jangka masa panjang kepada pembangunan masyarakat dan penghasilan guna tenaga negara secara keseluruhannya.

Masih kurang kajian mengenai hubungan antara tekanan akademik dan kesejahteraan diri pelajar universiti di Malaysia. Kajian lepas lebih banyak memfokus kepada hubungan antara tekanan dan pencapaian akademik (Elias, Ping \& Abdullah, 2011) dan antara kecerdasan emosi, keperluan psikologi asas (Alim et. al, 2016) dan sokongan sosial (Muhammad Ashraf, Fauziah \& Suhaya, 2019) dengan kesejahteraan diri. Justeru, kajian yang mengukur perkaitan antara tekanan akademik dan kesejahteraan diri pelajar universiti ini perlu dijalankan bagi menyumbang kepada pengkayaan ilmu dalam bidang di samping boleh menjadi rujukan serta asas kepada sebarang langkah atau strategi intervensi yang boleh diambil oleh pihak berautoriti khususnya universiti bagi memastikan kesejahteraan diri pelajar diberi perhatian sewajarnya.

\section{SOROTAN KAJIAN LEPAS}


Kesejahteraan psikologi merupakan suatu konsep yang bersifat multidimensi yang merangkumi aspek seperti keyakinan diri, kawalan kendiri, rasa kepentingan serta bebas daripada kegagalan, keresahan dan kesunyian (Bordbar, Nikkar, Yazdani \& Alipoor, 2011). Definisi ini selari dengan definisi oleh Ryff dan Singer (2008) iaitu kesejahteraan psikologi dapat dikenal pasti sebagai kebahagiaan, kepuasan hidup dan tidak menunjukkan gejala-gejala kemurungan. Menurut Boehm \& Kubzansky (2012), kebahagiaan adalah hasil daripada kesejahteraan psikologi dan merupakan tujuan tertinggi yang ingin dicapai oleh setiap manusia.

Apabila tahap kesejahteraan diri menurun biasanya individu akan mengalami keadaan yang dipanggil depresi atau kemurungan. Penyakit depresi dan mental secara langsungnya akan meninggalkan kesan negatif kepada tahap kefungsian pelajar universiti. Selain itu, kegagalan pelajar dalam menghadapi depresi boleh membawa kepada tahap pencapaian akademik yang rendah, tingkah laku pelik dan nakal, anoreksia dan bulimia, serangan-serangan panik, penyalahgunaan dadah, lari daripada rumah atau cubaan membunuh diri (Hammen, 2009).

Tekanan akademik ditakrifkan sebagai keadaan tidak menggembirakan akibat tuntutan-tuntutan yang perlu dipenuhi oleh pelajar universiti yang mencetuskan kebimbangan dalam pencapaian akademik dan ia mempengaruhi tahap kesejahteraan pelajar di semua peringkat pengajian secara lazimnnya. Kajian lepas (Brown et al., 1999; Towbes \& Cohen, 1996; Pancer et al., 2000; Wintre \& Yaffe, 2000) menunjukkan pelajar universiti tahun pertama didapati terdedah kepada tekanan akademik yang tinggi disebabkan oleh faktor peralihan kehidupan dan institusi pengajian. Kesan tekanan yang signifikan dan paling kerap dilaporkan adalah seperti kemurungan, sakit kepala, insomnia, kesunyian, kerinduan kepada keluarga (homesickness) yang melampau, dan peningkatan dalam jumlah aktiviti merokok.

Faktor akademik dikenal pasti sebagai faktor dominan yang mendorong kepada tekanan dalam kalangan pelajar universiti, diikuti oleh faktor fizikal, sosial dan emosi. Antara punca tekanan akademik adalah terlalu banyak tugasan yang diberikan oleh pensyarah, persaingan dengan pelajar lain, kegagalan dan hubungan persahabatan yang renggang dengan rakan sebaya, peperiksaan dan pengharapan ibu bapa dan pensyarah (Fairbrother \& Warn, 2003). Kajian oleh Sohail (2013) mendapati terdapat korelasi negatif yang signifikan antara tekanan akademik dengan pencapaian akademik pelajar universiti. Ini bermaksud apabila pelajar mendapat skor tekanan yang tinggi, skor pencapaian akademiknya pula adalah rendah. Begitu juga sebaliknya. Kajian yang dijalankan oleh Baste \& Gadkari (2014) mendapati majoriti pelajar yang mengalami tekanan mempunyai skor yang rendah dalam estim kendiri dan skor yang tinggi dalam depresi.

Harikiran et al., (2012) mendapati faktor akademik yang paling kerap dilaporkan sebagai faktor yang menyumbang kepada tekanan akademik dan kebimbangan adalah tempoh peperiksaan, beban bidang kursus yang berat, kekurangan melakukan aktiviti bersukan dan bersenam, dan tempoh peperiksaan yang panjang. Persepsi bebanan kursus, kursus yang sukar, persiapan menghadapi peperiksaan dan tempoh peperiksaan yang panjang didapati sebagai sumber utama mendorong kepada tekanan akademik dan mempengaruhi tahap kesejahteraaan diri pelajar.

Selain daripada itu, kajian yang dilakukan oleh Marsh et al., (2015) mendapati bahawa pelajar yang menilai diri mereka dengan positif mampu memperuntukkan dan menyusun waktu belajar dengan lebih efisien dan mampu mendapat keputusan yang cemerlang dalam peperiksaan. Faktor persespi diri akademik memainkan peranan dalam meningkatkan motivasi dan keyakinan untuk belajar dalam bidang akademik. Menurut Chevalier (2007) persepsi diri akademik adalah satu indikator untuk pelajar berjaya dalam bidang akademik dan kerjaya pada masa depan, ia juga merupakan prediktor dalam meningkatkan kecemerlangan pelajar dan seterusnya kesejahteraan diri pelajar di universiti. Kajian oleh Abouserie (1994) pula mendapati terdapat hubungan yang signifikan antara tekanan akademik dengan kesejahteraan pelajar, gangguan psikologi dan masalah pelajar.

Faktor kekangan dan pengurusan masa yang lemah juga mendorong kepada penurunan prestasi akademik dan kesejahteraan diri pelajar universiti (Hamizatun Akmal \& Norzaini, 2013). Menurut Bedewy dan Gabriel (2015), kekangan masa merujuk kepada tekanan yang menunjukkan situasi pelajar mempunyai masa yang terhad untuk kelas, ketidakupayaan untuk menyiapkan tugasan, kesukaran untuk mengejar silibus dalam topik pembelajaran dan mempunyai masa terhad untuk berehat. Kajian oleh Kearns dan Gardiner (2007) mendapati 
bahawa kegagalan pelajar dalam menguruskan masa dengan baik telah dikenalpasti sebagai salah satu faktor yang mendorong kepada tekanan akademik dan kebimbangan dalam kalangan pelajar.

Dapatan kajian perbandingan kesejahteraan diri antara jantina adalah pelbagai. Kajian oleh Akhter (2015) dan Hasnain, Wazid \& Hasan (2014), menunjukkan terdapat perbezaan yang signifikan dalam kesejahteraan diri antara responden lelaki dan perempuan. Namun, dapatan yang berbeza diperolehi dalam kajian Hasan (2016). Kajian Hasan (2016) juga mendapati tiada perbezaan yang signifikan dalam kesejahteraan diri responden berdasarkan jurusan sains dan sains sosial. Oleh itu, berdasarkan kajian-kajian lepas, objektif kajian ini adalah seperti berikut:

1. Memperihal tahap tekanan akademik dan kesejahteraan pelajar universiti.

2. Menentukan perkaitan antara tekanan akademik dengan kesejahteraan diri pelajar universiti.

3. Membandingkan kesejahteraan diri pelajar universiti mengikut kategori jantina dan jurusan pengajian.

4. Menentukan faktor peramal unik kesejahteraan pelajar universiti.

\section{METODOLOGI KAJIAN}

\section{Sampel dan Prosedur}

Kajian ini menggunakan pendekatan kuantitatif dan reka bentuk yang dipilih adalah penyelidikan korelasi dan deskriptif. Reka bentuk korelasi dipilih kerana kajian ini bertujuan mengukur perkaitan antara pemboleh ubah bersandar iaitu kesejahteraan diri pelajar Universiti Putra Malaysia di Serdang, Selangor dengan pemboleh ubah bebas iaitu tekanan akademik. Survei melalui borang soal selidik digunakan untuk proses pengumpulan data. Kaedah persampelan yang digunakan dalam kajian ini adalah persampelan rawak berlapis. Responden yang dipilih terdiri daripada pelajar pelbagai jantina dan jurusan daripada empat buah kolej kediaman. Penentuan saiz sampel adalah berdasarkan formula oleh Kerjcie \& Morgan (1970) dan pengiraan dibuat ke atas populasi berjumlah 14,063:

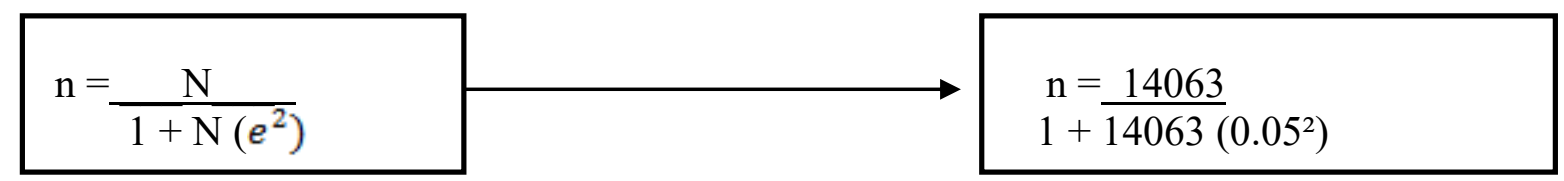

$*_{\mathrm{n}}=388.94, \mathrm{n}=400$ orang pelajar

Merujuk kepada formula di atas, $\mathrm{n}$ ialah sampel yang diperlukan manakala nilai $e$ adalah bersamaan dengan confidence interval $= \pm 5 \%, e=0.05$ yang memberi nilai saiz sampel adalah sebanyak $\mathrm{n}=388.94$. Nilai ini adalah nilai minimum untuk saiz sampel tersebut. Untuk mengurangkan risiko berkaitan data kajian, $n=400$ responden telah dipilih. Kerahsiaan maklumat yang diberi dan penggunaannya hanyalah untuk tujuan kajian ini sahaja telah dijelaskan kepada setiap responden sebelum borang soal selidik diberikan kepada mereka.

\section{Pengukuran}

Personal Wellbeing Index-Adult (PWI-A) oleh Cummins dan Lau (2005) telah digunakan untuk mengukur tahap kesejahteraan diri pelajar universiti. Nilai alpha bagi kebolehpercayaan skala untuk instrumen dalam kajian ini ialah 0.84 . Terdapat sembilan item berkaitan dengan kesejahteraan diri pelajar dalam instrumen ini iaitu 1) kesejahteraan diri secara keseluruhan, 2) taraf hidup, 3) kesihatan, 4) pencapaian hidup, 5) hubungan peribadi, 6) keselamatan peribadi, 7) hubungan komuniti, 8) keselamatan masa hadapan, (9) kerohanian/keagamaan. Pengukuran adalah melalui sepuluh skala likert daripada skala 1 (Tiada Kepuasan Langsung) hingga skala 10 (Berasa Puas Sepenuhnya). Jumlah skor yang tinggi menunjukkan tahap kesejahteraaan diri yang tinggi. 
Manakala, tekanan akademik pula diukur dengan menggunakan Perception of Academic Stress Scale $(P A S)$ oleh Bedewy\& Gabriel(2015). Terdapat 18 item yang mengukur tekanan akademik pelajar universiti dan terbahagi kepada 4 subskala, iaitu 1) tekanan prestasi, 2) persepsi bebanan kerja dan peperiksaan, 3) persepsi diri akademik, 4) kekangan masa. Subskala tekanan prestasi mempunyai 5 item, subskala persepsi bebanan kerja dan peperiksaan mempunyai 4 item, subskala persepsi diri mempunyai 4 item dan subskala kekangan masa mempunyai 5 item. Jadual 1 dibawah menunjukkan subskala bagi pembolehubah persepsi tekanan akademik. Pengukuran adalah melalui lima skala likert daripada 1 (sangat tidak benar) sehingga 5 (sangat benar). Skor yang tinggi menunjukkan tahap tekanan akademik yang tinggi. Nilai kebolehpercayaan tekanan akademik ialah 0.70 .

Jadual 1 Subskala tekanan akademik

\begin{tabular}{|c|c|}
\hline Subskala & Item \\
\hline Tekanan prestasi akademik (5 item) & $\begin{array}{l}\text { 1. Persaingan dengan rakan-rakan untuk gred adalah agak sengit. } \\
\text { 2. Jangkaan yang tidak realistik daripada ibu bapa memberi } \\
\text { tekanan kepada saya. } \\
\text { 3. Pensyarah adalah kritikal terhadap prestasi akademik saya. } \\
\text { 4. Masa peperiksaan sangat memberikan tekanan kepada saya. } \\
\text { 5. Saya berfikiran bahawa kebimbangan terhadapp peperiksaan } \\
\text { adalah kelemahan karakter saya. }\end{array}$ \\
\hline $\begin{array}{l}\text { Persepsi Bebanan Kerja } \\
\text { Dan Peperiksaann (4 item) }\end{array}$ & $\begin{array}{l}\text { 1. Saya percaya bahawa jumlah tugasan kerja terlalu banyak. } \\
\text { 2. Saiz kurikulum (beban kerja) adalah berlebihan. } \\
\text { 3. Soalan peperiksaan kebiasaanya adalah susah. } \\
\text { 4. Walaupun jika saya lulus peperiksaan, saya berasa bimbang } \\
\text { untuk mendapatkan pekerjaan. }\end{array}$ \\
\hline Persepsi Diri Akademik (4 item) & $\begin{array}{l}\text { 1. Saya yakin yang saya akan berjaya dalam kerjaya di masa hadapan. } \\
\text { 2. Saya yakin saya akan menjadi seorang pelajar yang berjaya. } \\
\text { 3. Saya berasa takut akan gagal dalam kursus tahun ini. } \\
\text { 4. Saya boleh membuat keputusan akademik dengan mudah. }\end{array}$ \\
\hline Kekangan Masa ( 5 item) & $\begin{array}{l}\text { 1. Saya mempunyai masa yang mencukupi untuk berehat } \\
\text { selepas menyiapkan tugasan kerja. } \\
\text { 2. Masa yang diperuntukkan kepada kelas dan tugasan kerja } \\
\text { akademik adalah mencukupi. } \\
\text { 3. Pensyarah mempunyai jangkaan tidak realistik terhadap saya. } \\
\text { 4. Masa peperiksaan adalah singkat untuk menyiapkan jawapan. } \\
\text { 5. Saya tidak dapat mengikuti sesuatu topik jika saya ketinggalan. }\end{array}$ \\
\hline
\end{tabular}

\section{ANALISIS DATA KAJIAN}

Kajian data yang diperoleh dianalisis dengan menggunakan program Statistical Package for Social Science (SPSS). Statistik deskriptif telah digunakan untuk memperihal ciri personal pelajar universiti, tekanan akademik dan kesejahteraan diri pelajar iaitu Objektif 1 kajian. Bagi menjawab Objektif 2, Ujian Pekali Korelasi Pearson pula telah digunakan untuk menentukan perkaitan antara persepsi tekanan akademik dengan kesejahteraan diri dalam pelajar universiti. Seterusnya, Ujian T digunakan bagi menentukan perbezaan kesejahteraan diri pelajar mengikut kategori jantina iaitu bagi menjawab Objektif 3. Bagi menjawab Objektif 4 pula, ujian Regrasi Berganda telah digunakan iaitu untuk menentukan faktor peramal unik bagi kesejahteraan diri pelajar universiti.

\section{HASIL KAJIAN}




\section{Ciri Personal Responden}

Jadual 2 menjelaskan tentang jantina responden di mana 160 orang merupakan pelajar lelaki manakala 240 orang yang lain merupakan pelajar perempuan. Pelajar lelaki adalah sebanyak 40 peratus manakala pelajar perempuan sebanyak 60 peratus (mengikut analisis Bahagian Hal Ehwal Pelajar UPM 2018 - ratio bilangan pelajar lelaki kepada perempuan ialah 4:6). Nisbah ini diguna pakai bagi memperolehi dapatan kajian yang adil. Responden terdiri daripada pelajar tahun satu iaitu 151 orang (37.8 peratus), pelajar tahun dua iaitu 136 orang (34 peratus), pelajar tahun tiga iaitu 80 orang (20 peratus) dan pelajar tahun empat iaitu 33 orang (8.3 peratus). Seterusnya, jumlah responden daripada jurusan Sains Sosial adalah seramai 229 orang (57.3 peratus) manakala daripada jurusan Sains adalah seramai 171 orang (42.8 peratus).

Jadual 2 Ciri Personal Pelajar $(n=400)$

\begin{tabular}{lll}
\hline Jantina & 160 & 40.0 \\
Lelaki & 240 & 60.0 \\
Perempuan & 151 & 37.8 \\
\hline Tahun Akademik & 136 & 34.0 \\
Satu & 80 & 20.0 \\
Dua & 33 & 8.3 \\
Tiga & & \\
Empat & 229 & 57.3 \\
\hline Jurusan & 171 & 42.8 \\
Sains Sosial & & \\
Sains & & \\
\hline
\end{tabular}

Tahap Tekanan Akademik dan Kesejahteraan Pelajar

Jadual 3 menunjukkan tahap tekanan akademik pelajar yang dibahagikan kepada tiga iaitu tahap rendah, sederhana dan tinggi. Pengiraan ini berdasarkan kajian oleh Aiken dan West (1991) iaitu Mean $\pm S D$. Hasil kajian melaporkan sebanyak 69.3 peratus $(\mathrm{n}=277)$ pelajar mempunyai tahap tekanan akademik yang tinggi. Ini diikuti dengan 30.3 peratus $(n=121)$ pelajar melaporkan mempunyai tahap tekanan akademik yang sederhana. Hanya 0.5 peratus $(n=2)$ pelajar melaporkan mempunyai tahap tekanan akademik yang rendah.Secara keseluruhan dapatan kajian ini menunjukkan kebanyakan pelajar mempunyai tahap tekanan akademik pada tahap tinggi. Skor tekanan akademik yang tinggi menunjukkan pelajar mengalami tekanan dalam aspek tekanan prestasi, persepsi bebanan kerja dan peperiksaan, persepsi diri akademik, kekangan masa.

Jadual 3 Tekanan Akademik $(n=400)$

\begin{tabular}{lcc}
\hline \multicolumn{1}{c}{ Tekanan Akademik } & Kekerapan & Peratus(\%) \\
\hline Rendah (18-42) & 2 & 0.5 \\
Sederhana (43-61) & 121 & 30.3 \\
Tinggi (62-90) & 277 & 69.3 \\
\hline Jumlah & 400 & 100.0 \\
Keciciran & 0 & 0 \\
\hline
\end{tabular}

Jadual 4 menunjukkan terdapat tiga tahap kesejahteraan pelajar iaitu rendah, sederhana dan tinggi. Pengiraan ini mengikut berdasarkan kajian Cummins et al., (2005) iaitu hasil tambah setiap item dan menggunakan formula Mean $\pm S D$ (Aiken \& West, 1991). Hasil kajian mendapati majoriti pelajar, iaitu sebanyak 99.3 peratus $(n=397)$ melaporkan mempunyai tahap kesejahteraan diri pada tahap tinggi. Manakala, 0.50 peratus $(\mathrm{n}=2)$ pelajar melaporkan tahap kesejahteraan diri yang sederhana. Hanya 0.30 peratus $(\mathrm{n}=1)$ responden yang 
melaporkan mempunyai tahap kesejahteraan yang rendah. Secara keseluruhan, ini bermaksud kebanyakan pelajar gembira dengan kehidupan mereka dan boleh menjalankan peranan sebagai pelajar universiti dengan baik.

Jadual 4 Kesejahteraan Diri Pelajar $(n=400)$

\begin{tabular}{lcc}
\hline \multicolumn{1}{c}{ Kesejahteraan Diri Pelajar } & Kekerapan & Peratus(\%) \\
\hline Rendah (21-49) & 1 & 0.30 \\
Sederhana (50-78) & 2 & 0.50 \\
Tinggi (79-105) & 397 & 99.3 \\
\hline Jumlah & 400 & 100.0 \\
Keciciran & 0 & 0 \\
\hline
\end{tabular}

\section{Perbezaan dalam Kesejahteraan Diri Pelajar Berdasarkan Jantina dan Jurusan}

Ujian $\mathrm{T}$ telah dilakukan dan dapatan kajian menunjukkan tidak terdapat perbezaan yang signifikan dalam kesejahteraan diri antara pelajar lelaki dan perempuan $(\mathrm{t}=-0058, \mathrm{p}=0.954)$. Dapatan ini menyokong kajian oleh Akhter (2015) yang juga mendapati tiada perbezaan dalam kesejahteraan diri berdasarkan jantina. Dapatan kajian lepas berkaitan perbezaan dalam kesejateraan diri berdasarkan jantina sebenarnya adalah bercampur-campur. Sebagai contoh, kajian oleh Glozah (2013) mendapati terdapat perbezaan yang signifikan dalam kesejahteraan diri berdasarkan jantina di mana pelajar lelaki mempunyai kesejahteraan diri lebih tinggi berbanding pelajar perempuan.

Jadual 5 Perbezaan dalam Kesejahteraan Diri Pelajar Berdasarkan Jantina (n: 400)

\begin{tabular}{llllll}
\hline Pembolehubah & N & Min & Sd. & $\boldsymbol{t}$ & $\boldsymbol{P}$ \\
\hline Jantina & & & & -0.058 & 0.954 \\
\hline Lelaki & 160 & 65.9 & 14.482 & & \\
Perempuan & 240 & 65.7 & 11.933 & & \\
\hline
\end{tabular}

Hasil kajian juga mendapati bahawa tidak terdapat perbezaan yang signifikan dalam kesejahteraan diri pelajar di antara pelajar jurusan sains sosial dan sains $(\mathrm{t}=1.749, \mathrm{p}=0.081)$. Hasil kajian ini menyokong kajian yang dilakukan oleh Hasan (2016) dan Azman (2013) yang mendapati tiada perbezaan dalam kesejahteraan diri antara pelajar jurusan sains sosial dan sains di universiti. Fakta ini menjelaskan jurusan pengajian bukan faktor yang menentukan tahap kesejahteraan pelajar universiti.

Jadual 6 Perbezaan Dalam Kesejahteraan Diri Pelajar Berdasarkan Jurusan (n: 400)

\begin{tabular}{llllll}
\hline Pembolehubah & N & Min & Sd. & $\boldsymbol{t}$ & $\boldsymbol{P}$ \\
\hline Jantina & & & & 1.749 & 0.081 \\
\hline Sains Sosial & 229 & 66.61 & 12.778 & & \\
Sains & 171 & 64.32 & 13.205 & & \\
\hline
\end{tabular}

\section{Perkaitan antara Tekanan Akademik (Tekanan Prestasi, Persepsi Bebanan Kerja dan Peperiksaan, Persepsi Diri Akademik, Kekangan Masa) dengan Kesejahteraan Diri Pelajar.}

Bagi menentukan perkaitan antara tekanan prestasi dengan kesejahteraan responden ujian Pekali Korelasi telah dijalankan. Tekanan akademik bermaksud suatu tekanan dan ketegangan mental disebabkan oleh mempunyai kognitif negatif berkaitan peperiksaan, bebanan kerja tugasan yang berat dan didorong oleh kemampuan dan keyakinan diri yang rendah serta prestasi akademik yang lemah (Hancock et al., 1998). Hasil 
kajian ini menunjukkan bahawa tiada perkaitan yang signifikan antara tekanan prestasi dengan kesejahteraan diri pelajar kerana nilai $r=0.084$ dan nilai $p=0.093$ (rujuk jadual 6). Ini bermaksud tekanan prestasi tidak mempengaruhi kesejahteraan diri pelajar. Dapatan kajian ini bertentangan dengan dapatan kajian oleh Ma, Siu dan Tse (2018) yang mendapati jangkaan daripada ibu bapa dan pensyarah yang tinggi terhadap prestasi akademik pelajar memberikan tekanan yang tinggi kepada pelajar untuk mencapai gred yang cemerlang dalam peperiksaan dan ujian. Hal yang sedemikian menyebabkan pelajar berasa tertekan dengan jangkaan tersebut dan mendorong kepada penurunan kesejahteraan diri pelajar.

Jadual 6 Perkaitan Tekanan Prestasi dengan Kesejahteraan Diri Pelajar (n:400)

\begin{tabular}{lcc}
\hline Pembolehubah & \multicolumn{2}{c}{ Tahap Kesejahteraan Diri Pelajar } \\
\cline { 2 - 3 } Tekanan Prestasi & $\mathrm{r}$ & $\mathrm{p}$ \\
& 0.084 & 0.093 \\
\hline
\end{tabular}

Perkaitan antara persepsi bebanan kerja dan peperiksaan dengan kesejahteraan diri pelajar telah diukur melalui analisis ujian Pekali Korelasi. Hasil kajian ini menunjukkan bahawa tiada perkaitan yang signifikan antara persepsi bebanan kerja dan peperiksaan dengan kesejahteraan diri pelajar kerana nilai $\mathrm{r}=0.079$ dan nilai $\mathrm{p}=0.116$ (rujuk Jadual 7). Ini bermakna bahawa persepsi bebanan kerja tidak mempengaruhi kesejahteraan diri pelajar.

Dapatan kajian ini didapati bertentangan dengan dapatan kajian Yusof (2010) yang menunjukkan bahawa terdapat perkaitan antara bebanan kerja dan peperiksaan dengan kesejahteraan diri pelajar. Kajian yang dijalankan oleh Carveth (2016) juga menyatakan pelajar mengalami tekanan akademik apabila menghadapi musim peperiksaan yang memberi tekanan kepada emosi pelajar, persaingan gred dengan pelajar lain dan mempunyai terlalu banyak silibus untuk dipelajari untuk peperiksaan.

Jadual 7 Perkaitan Persepsi Bebanan Kerja dan Peperiksaan dengan Kesejahteraan Diri Pelajar (n:400)

\begin{tabular}{lcccc}
\hline Pembolehubah & & \multicolumn{2}{c}{ Tahap Kesejahteraan Diri Pelajar } \\
\cline { 3 - 4 } & & $\mathrm{r}$ & $\mathrm{p}$ \\
$\begin{array}{l}\text { Persepsi Bebanan } \\
\text { Peperiksaan }\end{array}$ & Kerja & Dan & 0.079 & 0.116 \\
\hline Nota: $\mathrm{p} \leq 0.05,{ }^{* *} \mathrm{p} \leq 0.01, * * * \mathrm{p} \leq 0.001$ & & & \\
\hline
\end{tabular}

Ujian Pekali Korelasi telah digunakan untuk menentukan perkaitan antara persepsi diri akademik dengan kesejahteraan diri pelajar. Hasil ujian menunjukkan bahawa terdapat perkaitan yang signifikan dan positif di antara persepsi diri akademik dengan kesejahteraan diri pelajar kerana nilai $\mathrm{r}=0.247^{* *}$ dan nilai $\mathrm{p}=0.000$ (Jadual 8). Ini bermaksud persepsi diri akademik mempengaruhi kesejahteraan diri pelajar di mana semakin tinggi skor persepsi diri akademik yang diperolehi, semakin tinggi kesejahteraan diri pelajar. Dengan perkataan lain, persepsi diri akademik menentukan kesejahteraan diri pelajar samada tinggi mahupun rendah. Hasil kajian ini konsisten dengan kajian oleh Chemers (2001) yang mendapati pelajar yang mempunyai persepsi diri yang positif menganggap tugas atau tekanan sebagai cabaran dan mereka lebih cenderung untuk memilih strategi yang lebih kompeten untuk mengatasi cabaran tersebut.

Jadual 8 Perkaitan Persepsi Diri Akademik dengan Kesejahteraan Diri Pelajar (N:400)

\begin{tabular}{lcc}
\hline Pembolehubah & \multicolumn{2}{c}{ Tahap Kesejahteraan Diri Pelajar } \\
\cline { 2 - 3 } Persepsi Diri Akademik & $\mathrm{r}$ & $\mathrm{p}$ \\
& $0.247^{* *}$ & 0.000 \\
\hline
\end{tabular}

Perkaitan antara kekangan masa dengan kesejahteraan diri pelajar dalam kajian ini dianalisis menggunakan Ujian Pekali Korelasi. Kekangan masa merujuk kepada tekanan yang menunjukkan situasi pelajar 
mempunyai masa yang terhad untuk kelas, ketidakupayaan untuk menyiapkan tugasan, kesukaran untuk mengejar silibuk dalam topik pembelajaran dan mempunyai masa terhad untuk berehat. Hasil ujian menunjukkan bahawa terdapat perkaitan yang signifikan antara kekangan masa dengan kesejahteraan diri pelajar kerana nilai $\mathrm{r}=0.179^{* *}$ dan nilai $\mathrm{p}=0.000$. (Jadual 9). Nilai $\mathrm{p}$ yang kurang daripada 0.05 menunjukkan terdapat perkaitan negative yang signifikan antara dua pemboleh ubah yang berkaitan. Dapatan kajian menunjukkan semakin tinggi persepsi diri akademik, semakin menurun kesejahteraan diri pelajar.

Dapatan kajian ini menyokong kajian Kearns dan Gardiner (2007) yang mendapati kegagalan pelajar dalam menguruskan masa dengan baik telah dikenalpasti sebagai salah satu faktor mendorong kepada tekanan akademik dan kebimbangan dalam kalangan pelajar universiti. Dapatan kajian oleh Bedewy dan Gabriel (2015) membuktikan semakin banyak tugasan yang dipikul oleh pelajar, semakin tinggi kekangan masa untuk menyiapkan tugasan yang akhirnya mendorong kepada peningkatan tekanan akademik pelajar. Pelajar kebiasaanya mempunyai banyak tugasan yang perlu disiapkan dalam satu semester bagi setiap kursus yang diambil. Ringkasnya, peningkatan dalan tekanan akademik dari aspek kekangan mempengaruhi kesejahteraan pelajar di universiti.

Jadual 9 Perkaitan kekangan masa dengan kesejahteraan diri pelajar (n:400)

\begin{tabular}{lcc}
\hline Pembolehubah & \multicolumn{2}{c}{ Tahap Kesejahteraan Diri Pelajar } \\
\cline { 2 - 3 } Kekangan Masa & $\mathrm{r}$ & $\mathrm{p}$ \\
& $0.179^{* *}$ & 0.000 \\
\hline
\end{tabular}

\section{Faktor Peramal Unik Kesejahteraan Diri Pelajar}

Seperti yang ditunjukkan dalam Jadual 10, analisis regrasi berganda yang dijalankan berjaya menghasilkan model regrasi yang signifikan. Persepsi diri akademik merupakan peramal utama (unik) terhadap kesejahteraan diri pelajar. Sebanyak 12 peratus varian $\left(R^{2}=0.12\right)$ kesejahteraan diri pelajar dijelaskan oleh persepsi diri akademik dengan nilai $F=10.699$ pada aras signifikan $p<0.00$ (rujuk Jadual 10). Nilai Beta $(\beta)$ menunjukkan faktor yang paling kuat mempengaruhi kesejahteraan diri pelajar adalah faktor persepsi diri akademik di mana nilai $\beta=0.230, p<0.01$ diikuti faktor kekangan masa dengan nilai $\beta=0.103, p<0.01$.

Dapatan kajian ini menyokong kajian oleh Chevalier et al., (2009) yang mendapati persepsi diri akademik (bagaimanana pelajar menilai prestasi akademik mereka) merupakan faktor terpenting dalam kesejahteraan diri pelajar. Hasil kajian ini juga selari dengan dapatan kajian Bedewy dan Gabriel (2015) yang mengesahkan persepsi diri akademik merupakan punca tekanan akademik yang mempengaruhi status akademik dan kesejahteraan diri pelajar di universiti. Persepsi diri akademik merupakan keupayaan, kebolehan dan keyakinan pelajar sebagai indikator untuk berjaya dalam bidang akademik dan kerjaya pada masa depan. Dengan perkataan lain, peranan dan faktor persepsi diri akademik sangat penting dalam meningkatkan kecemerlangan dan kesejahteraan diri pelajar di universiti.

Jadual 10 Analisis Regrasi Berganda Kesejahteraan Diri Pelajar (n:400)

\begin{tabular}{lccc}
\hline Pembolehubah & \multicolumn{3}{c}{ Kesejahteraan Diri Pelajar } \\
\hline & B & SE.B & Beta, $\boldsymbol{\beta}$ \\
\hline Jumlah Tahun Pendidikan Ibu & 1.961 & 0.945 & 0.099 \\
Persepsi Diri Akademik & 0.960 & 0.204 & 0.230 \\
Kekangan Masa & 0.668 & 0.315 & 0.103 \\
$R^{2}$ & & 0.120 & \\
Adjusted $R^{2}$ & & 0.108 & \\
F & & 10.699 & \\
\hline
\end{tabular}

IMPLIKASI KAJIAN 
Kajian ini boleh dijadikan rujukan kepada pelajar universiti agar lebih peka dengan faktor-faktor yang mempengaruhi tahap kesejahteraan diri mereka. Kesedaran dan pengetahuan tentang faktor yang berisiko mempengaruhi kesejahteraan berpunca daripada aspek akademik membolehkan langkah-langkah yang lebih efektif diambil untuk menanganinya. Selain daripada itu, kajian ini juga memberikan implikasi kepada pihak universiti di mana data kajian ini boleh menjadi asas kepada program advokasi dan intervensi untuk meningkatkan kesejahteraan diri pelajar. Sebagai contoh, berdasarkan dapatan ini Pusat Kaunseling Universiti boleh mengadakan program motivasi diri dan pengurusan masa yang lebih baik bagi meningkatkan keyakinan dan persepsi diri yang positif supaya pelajar lebih bersedia dalam menghadapi sebarang cabaran dan tekanan dalam kehidupan di kampus.

\section{KESIMPULAN}

Kesejahteraan diri adalah amat penting dalam menentukan kebahagian hidup seseorang individu. Terdapat beberapa faktor yang mempengaruhi kesejahteraan diri. Menurut Abouserie (1994) proses pembelajaran dan pengajaran yang berbentuk akademik seperti peperiksaan, terlalu banyak tugasan, kehendak diri untuk mencapai keputusan yang terbaik dan melaksanakan tugasan atau projek kursus/kelas merupakan punca utama tekanan dalam kalangan pelajar. Kajian ini menyimpulkan bahawa persepsi diri akademik adalah faktor yang paling mempengaruhi kesejahteraan pelajar universiti. Ini bermaksud, keyakinan tinggi seseorang pelajar terhadap kemampuan akademiknya boleh menjadi motivasi kepada usaha yang difokuskan untuk mencapai kejayaan. Persepsi diri akademik yang positif memudahkan seseorang pelajar menyesuaikan diri dengan persekitaran dan kaedah pembelajaran di universiti. Kejayaan mencapai prestasi akademik yang baik hasil persepsi diri dan penyesuaian yang mantap seterusnya akan menyumbang kepada kebahagian dan kesejahteraan diri pelajar. Akhirnya, pelajar berjaya menamatkan pengajian dengan jaya dan berupaya menjalankan kefungsiannya sebagai insan yang menyumbang bakti dalam keluarga, masyarakat dan negara.

\section{RUJUKAN}


Abouserie, R. (1994). Sources and Levels of Stress in Relation to Locus of Control and Self Esteem in University Students. Educational Psychology, 14(3), 323-330. https://doi.org/10.1080/0144341940140306

Acharya Pandey, R., \& Chalise, H. N. (2016). Self-esteem and academic stress among nursing students. Kathmandu University Medical Journal, 13(52), 298-302.

Aiken, L. S., \& West, S. G. (1991). Multiple Regression: Testing and interpreting interactions. Newbury Park, CA: Sage.

Akhter (2015). Psychological Well-Being in Student of Gender Difference. The International Journal of Indian Psychology, Volume 2, Issue 4, DIP: B00337V2I42015.

Alim, C.A, Rathakrishnan, B., Alim, A. \& Vooi, P. Hubungan Perfeksionisme, Keperluan Psikologi Asas Dan Kesejahteraan Psikologi dalam Kalangan Pelajar Universiti di Sabah, Jurnal Psikologi Malaysia 30 (2) (2016): 13-21.

Azman, N. (2013). Perkaitan Antara Pengurusan Masa Dan Stress Dalam Kalangan Pelajar Siswazah Di IPTA. Vol. 5, No.1, 34-49.

Bahls, S. C. (2002). Epidemiology of depressive symptoms in adolescents of a public school in Curitiba, Brazil. Revista Brasileira de psiquiatria, 24(2), 63-67

Baste, V.S. \& Gadkan,J.V. (2014).Study of stress, self-esteem and depression in medical students and effects of music on perceived stress. Indian journal of physiology and pharmacology.58, 294-301

Brown, M., \& Ralph, S. (1999). Using the DYSA programme to reduce stress and anxiety in first-year university students. Pastoral Care, 17(3), 8-13.

Bataineh, M. Z. (2013). Academic Stress among Undergraduate Students : The Case of Education Faculty at King Saud University. International Interdisciplinary Journal of Education, 2(1), 82-88.

Bedewy, D. and Gabriel, A. (2015). Examining perceptions of academic stress and its sources among university students: The Perception of Academic Stress Scale. Health Psychology Open, 2(2).

Bennett,T.H. \& Holloway, K.R. (2014). Drug misuse among university students in the U.K: Implications for prevention. Substance use and misuse.49 (4), 448-455

Boehm, J. K., \& Kubzansky, L. D. (2012). The heart's content: the association between positive psychological wellbeing and cardiovascular health. Psychological bulletin, 138(4), 655-691.

Bordbar, F. T., Nikkar, M., Yazdani, F., \& Ali-poor, A. (2011). Comparing the psycho-logical well-being level of the students of Shiraz Payame Noor University in view of demographic and academic per-formance variables.Procedia-Social and Behavioral Sciences, 29, 663-669

Carveth, W. B., \& Gottlieb, B. H. (2016). The measurement of social support and its relation to stress. Canadian Journal of Behavioural Science/Revue canadienne des sciences du comportement, 11(3), 179.

Cummins, R., \& Lau, A. (2005). Personal wellbeing index-school children. Victoria: Deakin University.

Chevalier, A., Gibbons, S., Thorpe, A., Snell, M., \& Hoskins, S. (2009). Students' academic self-perception. Economics of Education Review, 28(6), 716-727.

Chemers, M. M., Hu, L. T., \& Garcia, B. F. (2001). Academic self-efficacy and first-year college student performance and adjustment. Journal of Educational Psychology, 93(1), 55-64. https://doi.org/10.1037/0022-0663.93.1.5

Deb, S., Strodl, E.\& Sun, J.(2015). Academic stress, parental pressure, anxiety and mental health among Indian high school students. International Journal of Psychology and Behavioural Sciences. 5(1), 25-34.

Dwyer, A., \& Cummings, A. (2001). Stress, self-efficacy, social support, and coping strategies in university students. Canadian Journal of Counseling, 35, 208-220

Elias, H., Ping, W. S., \& Abdullah, M. C. (2011). Stress and academic achievement among undergraduate students in Universiti Putra Malaysia. In Procedia - Social and Behavioral Sciences. Vol. 29, pp. 646-655.

Fairbrother, K., \& Warn, J. (2003). Workplace dimensions, stress and job satisfaction. Journal of Managerial Psychology, 18(1-2), 8-21. https://doi.org/10.1108/02683940310459565

Furlong, M. (2016). Measuring student's well being in Promoting Students' Happiness: Positive Psychology Intervention Strategies in School-Based Practice, Suldo Book Chapter 2. (Professor, School Psychology Program, University of South Florida).

Glozah, Franklin. N. (2013). Effects of Academic Stress and Perceived Social Support on the Psychological Wellbeing of Adolescents in Ghana. Open Journal of Medical Psychology, 2013, 2, 143-150 http://dx.doi.org/10.4236/ojmp.2013.24022

Hammen, C., Kim, E. Y., Eberhart, N. K., \& Brennan, P. A. (2009). Chronic and acute stress and the prediction of major depression in women. Depression and anxiety, 26(8), 718-723.

Harikiran A G, Srinagesh J, Nagesh K S, Sajudeen N. (2012). Perceived sources of stress amongst final year dental under graduate students in a dental teaching institution at Bangalore, India: A cross sectional study. Indian J Dent Res, 23:331-6.

International Wellbeing Group (2013). Personal Wellbeing Index: 5th Edition. Melbourne: Australian 
Centre on Quality of Life, Deakin University

Jarden, A. (2012). Positive Psychologists on Positive Psychology. International Journal of Wellbeing, 2(2), 70-71.

Kajian Kesihatan Morbiditi Kebangsaan (2011). Methodology \& General Findings,10 January 2016.http://iku.moh.gov.my/images/IKU/Document/REPORT/NHMS2011VolumeI.pdf

Kearns, H., \& Gardiner, M. (2007). Is it time well spent? The relationship between time management behaviours, perceived effectiveness and work-related morale and distress in a university context. Higher Education Research \& Development, 26(2), 235-247. https://doi.org/10.1080/0729436070131083

King, K.A., Vidowel,R.A.\& Singh, A.(2014). Condoms, sex and STDs: Exploring sexual health issues among Asian Indian College students. Sexuality and Culture.18 (3), 649-663

Krejcie, R. V., \& Morgan, D. W. (1970). Determining sample size for research activities. Educational and psychological measurement, 30(3), 607-610.

Ma, Y., Siu, A., \& Tse, W. S. (2018). The Role of High Parental Expectations in Adolescents' Academic Performance and Depression in Hong Kong. Journal of Family Issues, 39(9), 2505-2522. https://doi.org/10.1177/0192513X18755194

Mahfar, M. and Nordin, N. (2007). Analisis faktor penyebab stres di kalangan pelajar. Jurnal Kemanusiaan, Vol 9.

Marsh, H. W., Lüdtke, O., Nagengast, B., Trautwein, U., Abduljabbar, A. S., Abdelfattah, F., \& Jansen, M. (2015). Dimensional comparison theory: Paradoxical relations between self-beliefs and achievements in multiple domains. Learning and Instruction, 35, 16-32. doi:10.1016/j.learninstruc.2014.08.005.

Hamizatun Akmal, Md Yusof \& Norzaini, Azman (2013). Perkaitan antara pengurusan masa dan stres dalam kalangan pelajar siswazah di IPTA. ASEAN Journal of Teaching and Learning in Higher Education, 5 (1). pp. 34-4.

Hasan, M (2016). Psychological Well-being and Gender Difference among Science and Social Science students. Indian Journal of Psychological Science, V-6, No.2, 151-158..

Hasnain, N., Wazid, S.W. \& Hasan, Z. (2014). Optimism, Hope , and Happiness as correlates of Psychological WellBeing among Young Adult Assamese Males and Females. IOSR Journal of Humanities and Social Science (IOSR-JHSS), Vol. 19 (11), 44-51.

(1) (PDF) Psychological Well-being and Gender Difference among Science and Social Science students. Available from: https://www.researchgate.net/publication/334459204_Psychological_Wellbeing_and_Gender_Difference_among_Science_and_Social_Science_students [accessed Jan 23 2020].

Muhammad Ashraf Zakaria, Faudziah Yusof \& Suhaya Deraman. Hubungan Sokongan Sosial dan Pengertian Hidup dalam Kalangan Pelajar di Kolej Kemahiran Tinggi Mara, Masjid Tanah Jurnal Sains Sosial, Jilid. 4 (1) 2019: 44-53.

Myers, J. E., \& Sweeney, T. J. (2007). Wellness in counseling: An overview (ACAPCD-09). Alexandria, VA: American Counseling Association.

Nor Hamidah Salleh, and Kasmini Kassim, (1995) Depression In Adolescent Runaways. Malaysian Journal of Psychiatry, 3 (2). pp. 51-58. ISSN 0128-8628.

Ryff, C. D., \& Singer, B. H. (2008). Know thy-self and become what you are: A eudai-monic approach to psychological well-being. Journal of Happiness Studies, 9(1), 13-39.

Rushton, J. L., Forcier, M., \& Schectman, R. M. (2002). Epidemiology of Depressive Symptoms in the National Longitudinal Study of Adolescent Health. Journal of the American Academy of Child and Adolescent Psychiatry, 41(2), 199-205. https://doi.org/10.1097/00004583-200202000-00014

Sohail, N. (2013). Stress and academic performance among medical students. Journal of the College of Physicians and Surgeons Pakistan, 23(1), 67-71.

Sarita, S. (2015). Academic Stress among Students: Role and Responsibilities of Parents. IJAR, 1(10), 385-388

Smetana, J. G., Campione-Barr, N., \& Metzger, A. (2005). Adolescent Development in Interpersonal and Societal Contexts. Annual Review of Psychology, 57(1), 255-284. https://doi.org/10.1146/annurev.psych.57.102904.190124

Wintre, M. G., \& Yaffe, M. (2000). First-year students' adjustment to university life as a function of relationships with parents. Journal of adolescent research, 15(1), 9-37

Yusoff, M. S. B. (2010). Stress, stressors and coping strategies among secondary school students in a Malaysian government secondary school: Initial findings. ASEAN Journal of Psychiatry, 11(2), 1-10.

Zhong, L.F., (2017). Academic Stress and Subjective Well-being: The Moderating Effects of Perceived Social Support. Scientific Research Fund of Renmin University of China, 1321-1324.

Zhang, J., \& Zheng, Y. (2017). How do academic stress and leisure activities influence college students' emotional well being? A daily diary investigation. Journal of Adolescence, 60,114-118. 
